\title{
Microwave Irradiation as a Way to Reutilize the Recovered Struvite Slurry and to Enhance System Performance
}

Joon Hee Cho, Jin Eui Lee and ChangSix Ra

Department of Animal Life System, Kangwon National University

\author{
회수된 MAP 슬러리의 재이용과 공정효율 향상을 위한 도구로서의 \\ 극초단파 조사 \\ 조준희 · 이진의 · 라창식 \\ 강원대학교 동물생명과학대학, 동물생명시스템학과
}

요 약

\begin{abstract}
회분식 반응조를 $\mathrm{Mg}$ 원 첨가 방법이나 혹은 $\mathrm{MAP}$ 을 재이용하는 조건이 서로 다른 4가지 상이한 조건하에서 운전하면서 공정으로부터 회수된 magnesium ammonium phosphate (MAP) 혹은 struvite 슬러리의 재이용 수단으로서의 극초단파조사 방법 의 이용 가능성을 파악하였다. 또한 극초단파조사 동안의 MAP 용해율과 $\mathrm{NH}_{4}-\mathrm{N}$ 소실양상 및 $\mathrm{MAP}$ 의 물리/화학적 변화를 분석하였다. $\mathrm{Mg}$ 원을 첨가하지 않은 run $\mathrm{A}$ 에서의 용해성 인과 암모니아성 질소의 제거율은 각각 $33 \%$ 와 $27 \%$ 수준이었던 반면 유입수내 용해성 인 기준 동몰비의 $\mathrm{Mg}$ 원을 첨가한 run $\mathrm{B}$ 에서는 용해성 인과 암모니아성 질소의 제거율이 각각 $87 \%$ 와 $40 \%$ 수준으로 증가하였다. 극초단파를 조사한 $\mathrm{MAP}$ 을 첨가한 run $\mathrm{C}$ 의 경우, 비록 $\mathrm{Mg}$ 원을 첨가한 run $\mathrm{B}$ 에 비해 $\mathrm{PO}_{4}-\mathrm{P}$ 와 $\mathrm{NH}_{4}-\mathrm{N}$ 제거율이 낮았으나, $\mathrm{Mg}$ 원을 첨가하지 않은 run A에 비해 $\mathrm{PO}_{4}-\mathrm{P}$ 의 제거율이 2배 정도 높아지는 결과를 보였다. $\mathrm{Mg}$ 원과 $\mathrm{MAP}$ 을 각각 $1 / 2$ 씩 첨가한 run $\mathrm{D}$ 에서의 $\mathrm{PO}_{4}-\mathrm{P}$ 와 $\mathrm{NH}_{4} \mathrm{-N}$ 제거효율은 각각 $88 \%$ 와 $35 \%$ 수준으로 $\mathrm{Mg}$ 원만을 1 몰비로 첨 가한 run $\mathrm{B}$ 와 거의 유사한 효율을 나타내었다. 이러한 결과에 의거 극초단파로 처리한 후 MAP을 재이용하는 방법은 공정 에서의 인과 질소의 제거율을 높임은 물론, $\mathrm{Mg}$ 원 사용량을 감소시키는 이중효과가 있음을 알 수 있었다. $\mathrm{MAP}$ 을 극초단파 로 조사하면서 $\mathrm{NH}_{4} \mathrm{~N}$ 농도변화를 관찰한 결과 극초단파조사 초기단계에서는 $\mathrm{NH}_{4}-\mathrm{N}$ 농도가 점차 증가하다가 온도가 $45^{\circ} \mathrm{C}$ 이상으로 상승함에 따라 용액으로부터 $\mathrm{NH}_{4}-\mathrm{N}$ 가 소실되기 시작하여 감소하였으며 극초단파조사 동안의 $\mathrm{PO}_{4}-\mathrm{P}$ 용해율은 초 기 MAP 농도에 비례하면서 $0.0091 \mathrm{x}^{0.6373} \mathrm{mg} / \mathrm{sec}$ 의 상관관계를 갖는 것으로 분석되었다. 또한 주사전자현미경을 이용한 극초 단파조사 동안의 MAP 크리스탈 구조변화실험 결과 극초단파 조사시 전자기적 진동력에 의해 단시간내에 MAP 크리스탈 구조가 작은 입방체 과립형태로 부숴지고 극초단파 조사가 지속됨에 따라 점차 용액내로 녹음을 알 수 있었다.
\end{abstract}

(Key words : Microwave, Struvite, $\mathrm{MAP}\left(\mathrm{MgNH}_{4} \mathrm{PO}_{4} 6 \mathrm{H}_{2} \mathrm{O}\right)$, Swine wastewater)

\section{I . INTRODUCTION}

Swine wastewater contains a significant amount of nitrogen and phosphorous which is a great threat to environment if it is not properly treated. Presence of high amount of nitrogen and phosphorus in the water is a cause of eutrophication (Lee et al., 2003) that is hazardous for environment. Some forms of nitrogen (ammonia, nitrite, and nitrate) produce toxicity in the water and affect on aquatic life and public health. Hence, great efforts have been made by researchers for the removal of nitrogen from wastewater through biological nitrification and denitrification(Welander et al.,
1998), ammonia stripping (Bonmati and Flotats, 2003), electrochemical conversion (Kim et al., 2006), ion exchange (Jeong et al., 2006) and magnesium ammonium phosphate (MAP) precipitation (Li et al., 1999; Yetilmezsoy and Zengin, 2009; Zhang et al., 2009). Biological nitrification and denitrification are suitable for low ammonia concentrated wastewater and air stripping consumes much energy for nitrogen removal. Digestion, dewater and disposal of wasted sludge through activated sludge process needs a high cost involvement to remove nitrogen (Eskicioglu et al., 2007).

Although chemical precipitation requires a lot of cost involvement due to chemical reagents, MAP or struvite

This study was funded by Korea Research Foundation (F00044).

Corresponding author : Dr. ChangSix Ra, Department of Animal Life System, Kangwon National University, Chunchon 200-701, South Korea. Tel: 033-250-8618, Fax: 033-251-7719, E-mail: changsix@kangwon.ac.kr 
recovery from wastewater would be an effective process for the simultaneous removal of nitrogen and phosphorus from wastewater, as well as for the recovery of resources that can be used as a highly valuable slowly releasing fertilizer (Munch and Barr, 2001). Struvite is a crystal of MAP formed in alkaline condition, and its chemical formula is $\mathrm{MgNH}_{4} \mathrm{PO}_{4} 6 \mathrm{H}_{2} \mathrm{O}$ and addition of $\mathrm{Mg}$ source in the wastewater enhances the struvite formation. Chirmuley (1994) stated that struvite is a white crystalline powder with a specific gravity of 1.7 and it is soluble in acid and insoluble in alkaline condition.

Because of its high levels of $\mathrm{NH}_{4}-\mathrm{N}$ and $\mathrm{PO}_{4}-\mathrm{P}$, animal wastewater can be a good source for the recovery of MAP. However, the molar ratio of $\mathrm{NH}_{4}-\mathrm{N}$ and $\mathrm{PO}_{4}-\mathrm{P}$ in animal wastewater is severely imbalanced (the molar ratio of $\mathrm{PO}_{4}-\mathrm{P}$ to $\mathrm{NH}_{4}-\mathrm{N}$ is approximately 0.008 ) and this acts as an obstacle for the simultaneous recovery of nitrogen and phosphorus using struvite crystallization method. For example, if $\mathrm{Mg}$ source addition is added based on $\mathrm{PO}_{4}-\mathrm{P}$ in influent to form MAP, the $\mathrm{NH}_{4}-\mathrm{N}$ removal is much lower since the crystallization of $\mathrm{Mg}^{2+}, \mathrm{NH}_{4}{ }^{+}$and $\mathrm{PO}_{4}{ }^{3-}$ occurs in equal molar ratio. In the contrary, if chemicals are added based on $\mathrm{NH}_{4}{ }^{+}$to enhance its removal efficiency, tremendous amount of $\mathrm{Mg}^{2+}$ and $\mathrm{PO}_{4}{ }^{3-}$ source must be added resulting to excessively high operational cost. To overcome these problems, a novel process should be developed that can eliminate the $\mathrm{NH}_{4}{ }^{+}$from the recovered MAP and reutilize it as $\mathrm{Mg}^{2+}$ and $\mathrm{PO}_{4}{ }^{3-}$ sources.

Microwave irradiation might be a successful strategy for the reduction of nitrogen from the wastewater and elimination of $\mathrm{NH}_{4}^{+}$from MAP. Lin et al. (2009) stated that 3 minutes microwave irradiation could remove more than $96 \% \mathrm{NH}_{4}-\mathrm{N}$ from a concentrated nitrogenous wasted solution. Recently, the researchers tried to use microwave (Ahn et al., 2004; Liao et al., 2005; Wojciechowska, 2005; Wong et al., 2006; Chan et al., 2007; Qureshi et al., 2008; Lin et al., 2009) to enhance the digestion and for removal of nitrogen from wastewater with a cheaper cost involvement. Microwave is an alternative to conventional heating that dramatically reduce the reaction time by reducing the wavelength and frequency in the electromagnetic spectrum (Eskicioglu et al., 2007). Martin et al. (2005) stated that the frequency of microwave irradiation ranged between $300 \mathrm{MHz}$ (million cycles per second) to $300 \mathrm{GHz}$ (billion cycles per second) which are smaller than ionizing radiation. Quick rise of temperature with microwave irradiation is due to molecular level of heating that leads to homogeneous and quick thermal reactions. Microwave heating saves considerable time and energy for a similar degree of heating compared to conventional ways (Menendez et al., 2002). Ponne and Bartels (1995) stated that chemical structures can be altered by the microwave energies. Instant hydrogen bonded structure requires very low energy for displacement of protons. During microwave irradiation, organic solvents can undergo superheating above their conventional boiling points and creates a significant difference compared to the boiling point (Saillard et al., 1995). Bi et al. (2007) stated that simultaneous microwave irradiation shortened the reaction time and increased the purities of the product.

Microwave irradiation was examined as a way to reutilize the MAP slurry recovered from animal wastewater as $\mathrm{Mg}$ source. Physical and chemical changes of MAP by microwave irradiation were also studied in this research.

\section{MATERIALS AND METHODS}

\section{System configuration and operational strategies}

The schematic diagram of the lab-scale experimental process is shown in Fig. 1. The reactor was made by Plexiglas. Total volume of the reactor was 2 liters and the working volume was 1 liter, and it was operated by batch mode. The sequence of the process was feeding (30 minutes) $\rightarrow$ aeration (22 hours) $\rightarrow$ settle (1 hour) $\rightarrow$ discharge (30 minutes) and the HRT was 3 days. Air was provided by an aerator through an air diffuser placed at the bottom of the reactor. The air flow rate was 1 liter/minute and the rate was controlled by a flow meter. The loading rate of influent, magnesium chloride $\left(\mathrm{MgCl}_{2}\right)$ and MAP were also controlled by

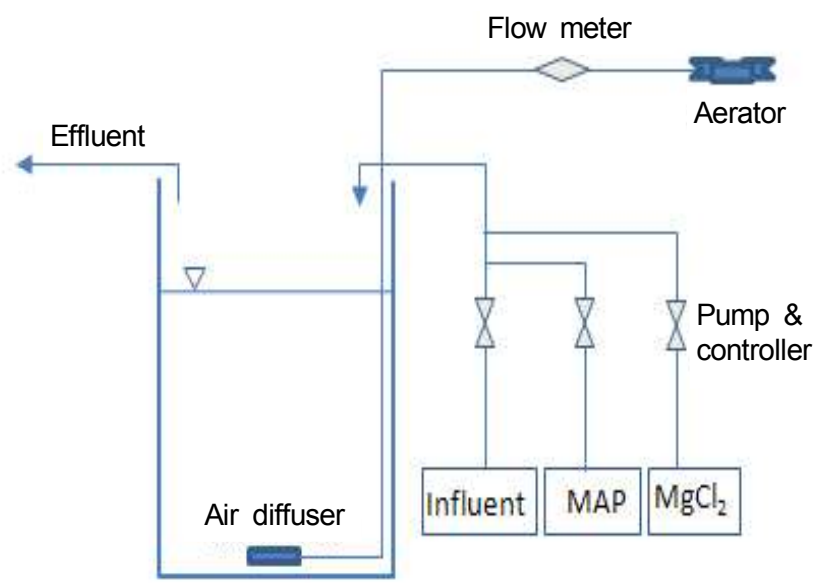

Fig. 1. Schematic diagram of the process. 
pumps. The $\mathrm{MgCl}_{2}$ and MAP were loaded into the reactor at the time of feeding according to experimental design.

Four operations were performed in this study as shown in Table 1. In run $\mathrm{A}$, no $\mathrm{MgCl}_{2}$ and $\mathrm{MAP}$ were added, while 1 molar ratio of $\mathrm{MgCl}_{2}$ and $\mathrm{MAP}$ to $\mathrm{PO}_{4}-\mathrm{P}$ of the influent was added in run $\mathrm{B}$ and $\mathrm{C}$ respectively. In run $\mathrm{D}$, both $\mathrm{MgCl}_{2}$ and MAP were added at the ratio of 0.5 mole to $\mathrm{PO}_{4}-\mathrm{P}$, respectively.

For run $\mathrm{C}$ and $\mathrm{D}$, magnesium hydroxide $\left(\mathrm{Mg}(\mathrm{OH})_{2}\right)$ and potassium hydroxyl phosphate $\left(\mathrm{KH}_{2} \mathrm{PO}_{4}\right)$ were added at 1 molar ratio to $\mathrm{NH}_{4}-\mathrm{N}$ in swine wastewater supernatant and aerated for 30 minutes to form MAP crystal. Then, the MAP mixture was collected after settling and centrifugation. The concentration of MAP mixture recovered in this manner was analyzed, and predetermined amount of MAP was passed through microwave irradiation for 4 minutes before loading into the reactor. The rate of microwave irradiation was maintained at $7.36 \mathrm{MHz} / \mathrm{mL}$ and a commercial microwave (SANYO, 2,450MHz, 10A) was used in this study.

\section{Influent wastewater and analytical methods}

Throughout the study, fresh swine wastewater was collected from a local farm. Prior to utilization, the swine wastewater was screened using a sieve with $0.5 \mathrm{~mm}$ mesh opening and centrifuged at $3000 \mathrm{rpm}$ for 5 minutes to remove solids before feeding into the influent container.

The influent and effluent samples of swine wastewater were taken from the respective bucket on every third day.

Table 1. Operational conditions of processes
Parameters routinely assayed included ortho-phosphate $\left(\mathrm{PO}_{4}-\mathrm{P}\right)$ and ammonium nitrogen $\left(\mathrm{NH}_{4}-\mathrm{N}\right) . \mathrm{PO}_{4}-\mathrm{P}$ and $\mathrm{NH}_{4}-\mathrm{N}$ were analyzed with an auto analyzer (Quick Chem 8000, LACHAT, USA).

\section{RESULTS AND DISCUSSION}

Table 2 shows the average $\mathrm{PO}_{4}-\mathrm{P}$ and $\mathrm{NH}_{4}-\mathrm{N}$ levels as well as the treatment efficiencies. Much difference in $\mathrm{PO}_{4}-\mathrm{P}$ and $\mathrm{NH}_{4}-\mathrm{N}$ removals was found among 4 different runs. Without addition of $\mathrm{Mg}$ source in Run $\mathrm{A}, 38 \% \mathrm{PO}_{4}-\mathrm{P}$ and $27 \% \mathrm{NH}_{4} \quad \mathrm{~N}$ removals occurred. Swine wastewater contains low level of $\mathrm{Mg}^{2+}$ and $\mathrm{Ca}^{2+}$ that can react with $\mathrm{NH}_{4}^{+}$and $\mathrm{PO}_{4}{ }^{3-}$ to form MAP, and this would be a cause of the partial removal of $\mathrm{PO}_{4}-\mathrm{P}$ and $\mathrm{NH}_{4}-\mathrm{N}$ in that run. Also, ammonia air stripping due to the extended aeration would contribute to the $\mathrm{NH}_{4}-\mathrm{N}$ removal.

When one molar ratio of $\mathrm{Mg}$ source to $\mathrm{PO}_{4}-\mathrm{P}$ in influent was added in run $\mathrm{B}$, the removal efficiency of $\mathrm{PO}_{4}-\mathrm{P}$ and $\mathrm{NH}_{4}-\mathrm{N}$ was $88 \%$ and $40 \%$, respectively. Comparing the $\mathrm{PO}_{4}-\mathrm{P}$ and $\mathrm{NH}_{4}-\mathrm{N}$ removal efficiencies between run $\mathrm{A}$ and $\mathrm{B}$, it was found that an external $\mathrm{Mg}$ source should be added in swine wastewater to achieve high removal of nitrogen and phosphorus through MAP crystallization, since struvite crystal is formed by $\mathrm{NH}_{4}{ }^{+}, \mathrm{Mg}^{2+}$ and $\mathrm{PO}_{4}{ }^{3-}$ at 1:1:1 molar ratio in a favorable condition (Jaffer et al., 2002; Suzuki et al., 2005).

When one molar ratio of MAP slurry was added after microwave irradiation for 4 minutes, $67 \%$ of $\mathrm{PO}_{4}-\mathrm{P}$ and $34 \%$ of $\mathrm{NH}_{4}-\mathrm{N}$ were removed in Run C. Although the obtained

\begin{tabular}{|c|c|c|c|c|}
\hline \multirow{2}{*}{ Condition } & \multicolumn{4}{|c|}{ RUN } \\
\hline & $\mathrm{A}$ & $\mathrm{B}$ & $\mathrm{C}$ & $\mathrm{D}$ \\
\hline Mg source & no & yes & no & yes $(1 / 2)$ \\
\hline MAP $^{*}$ reuse & no & no & yes & yes $(1 / 2)$ \\
\hline
\end{tabular}

* Magnesium Ammonium Phosphate (MAP)

Table 2. Efficiencies in each operation

\begin{tabular}{|c|c|c|c|c|c|c|c|c|c|c|}
\hline \multirow{3}{*}{ RUN } & \multicolumn{5}{|c|}{$\mathrm{PO}_{4}{ }^{3-}$} & \multicolumn{5}{|c|}{$\mathrm{NH}_{4}-\mathrm{N}$} \\
\hline & \multicolumn{2}{|c|}{ Influent } & \multicolumn{2}{|c|}{ Effluent } & \multirow{2}{*}{$\%$} & \multicolumn{2}{|c|}{ Influent } & \multicolumn{2}{|c|}{ Effluent } & \multirow{2}{*}{$\%$} \\
\hline & AVG & STED & AVG & STED & & AVG & STED & AVG & STED & \\
\hline $\mathrm{A}$ & 347.9 & 115.5 & 215.8 & 70.4 & 38.0 & 2673.3 & 259.4 & 1956.9 & 379.1 & 26.8 \\
\hline B & 323.5 & 106.6 & 37.8 & 22.0 & 88.3 & 2632.5 & 271.1 & 1593.9 & 436.1 & 39.5 \\
\hline $\mathrm{C}$ & 323.9 & 110.9 & 107.3 & 68.8 & 66.9 & 2721.0 & 269.5 & 1799.2 & 436.1 & 33.9 \\
\hline $\mathrm{D}$ & 320.3 & 108.4 & 32.4 & 22.0 & 89.9 & 2694.2 & 320.7 & 1747.3 & 436.4 & 35.1 \\
\hline
\end{tabular}


removal efficiencies were lower than run $\mathrm{B}\left(\mathrm{PO}_{4}-\mathrm{P}: 88 \%, \mathrm{NH}_{4}-\right.$ $\mathrm{N}: 40 \%$ ), the removal efficiencies of $\mathrm{PO}_{4}-\mathrm{P}$ and $\mathrm{NH}_{4}-\mathrm{N}$ were much enhanced when compared with run A. Especially, the $\mathrm{PO}_{4}$-P removal was almost double in this run by reutilizing the recovered MAP after microwave irradiation. This result might reveal that simple MAP recycling after microwave irradiation would be an effective way to enhance phosphorus and nitrogen removals from swine wastewater.

Removal efficiencies of $\mathrm{PO}_{4}-\mathrm{P}$ and $\mathrm{NH}_{4}-\mathrm{N}$ in run $\mathrm{D}$, where 0.5 molar ratio of $\mathrm{MgCl}_{2}$ plus 0.5 molar ratio of MAP (microwave irradiated for 4 minutes) were added as $\mathrm{Mg}$ source, were $90 \%$ and $35 \%$, respectively. The fact that the phosphorus removal was nearly similar to run B might mean that curtailment of chemical Mg usage would be feasible by operating the process as run D.

Track study of $\mathrm{NH}_{4}-\mathrm{N}$ concentration during the microwave irradiation of recovered struvite slurry is shown in Fig. 2. During microwave irradiation, gradual increase of $\mathrm{NH}_{4}-\mathrm{N}$ occurred up to 90 seconds, and then its level started to decrease gradually as the temperature increased up to $45^{\circ} \mathrm{C}$. It might be assumed that rapid dissolution of MAP was occurred with microwave irradiation, resulting in the increase of $\mathrm{NH}_{4}-\mathrm{N}$ at initial stage (up to 90 seconds), and this $\mathrm{NH}_{4}-\mathrm{N}$ started to emit as ammonia as temperature increased over $45^{\circ} \mathrm{C}$. The pattern of $\mathrm{NH}_{4}-\mathrm{N}$ change with microwave irradiation in this experiment is very much similar with Eskicioglu et al. (2007). They showed that $\mathrm{NH}_{4}-\mathrm{N}$ concentration of wasted activated sludge rapidly increased up to $50^{\circ} \mathrm{C}$ and then gradually decreased up to $75^{\circ} \mathrm{C}$, followed by a slow decrease up to $96^{\circ} \mathrm{C}$. During microwave irradiation, temperature increased gradually up to the end of heating. Initial irradiation up to $50^{\circ} \mathrm{C}$ helped to release ammonia from organic $\mathrm{N}$ and MAP dissolution, and then ammonia emission occurred at a higher temperature in

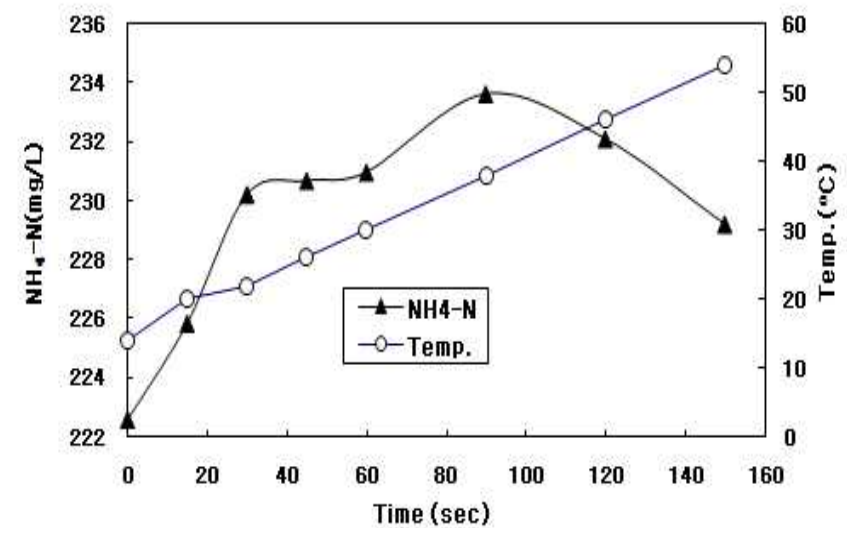

Fig. 2. Tracks of $\mathrm{NH}_{4}-\mathrm{N}$ and temperature during microwave irradiation. later stage of irradiation. Electro-magnetic vibration of microwave enhances the hydrolysis and also increases the temperature within a short time that helps to reduce ammonia. Sanz et al. (2003) stated that microwave heating was much higher than that of ordinary heating at the same conditions which enhance the oxidation and rate of reaction. Microwave irradiation reduced the heating time by its molecular vibration and dissociated the complex molecule into simpler form within a short time. Bi et al. (2007) stated that microwave irradiation could shorten the reaction time by $1 / 18$ times, which would greatly reduce the economical costs of catalytic oxidation process. Moreover, Martin et al. (2005) stated that microwave irradiation requires low energy to produce more output.

The relation between initial MAP concentration and dissolution rate of $\mathrm{PO}_{4}-\mathrm{P}$ during microwave irradiation are shown in Fig. 3. When initial concentration of MAP was 54 $\mathrm{mg} / \mathrm{L}$, the obtained dissolution rate during microwave irradiation was $0.1 \mathrm{mg} / \mathrm{sec}$, and when initial MAP concentration was $218 \mathrm{mg} / \mathrm{L}$ and $436 \mathrm{mg} / \mathrm{L}$, the dissolution rate was 0.3 $\mathrm{mg} / \mathrm{sec}$ and $0.45 \mathrm{mg} / \mathrm{sec}$, respectively. It might be stated that dissolution rate of $\mathrm{PO}_{4}{ }^{-3}$ during the microwave irradiation is function of the initial MAP concentration, having $0.0091 \mathrm{x}^{0.6373}$
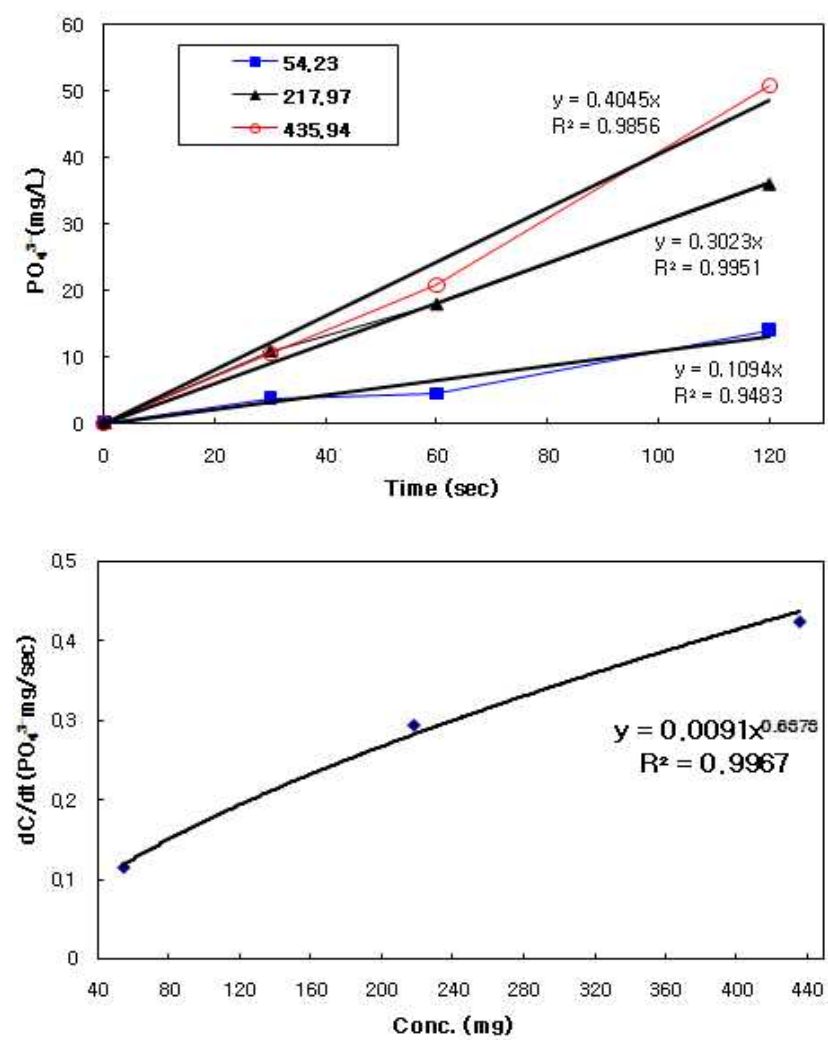

Fig. 3. Dissolution rate of MAP with microwave irradiation. 
correlation.

To figure out the physical change of MAP during microwave irradiation, the structure of MAP crystal was observed with SEM (scanning electron microscope) in an interval of $5 \mathrm{sec}$ for 30 seconds (Fig. 4). It was found that the MAP crystal had rhombic structure. Crack was observed at 10 seconds along with the MAP crystal and the crystal structure was broken down by producing lots of cubical granules within 15 seconds. After 25 seconds, the cubical granules started to melt down or started to disappear by electro-magnetic vibration force of microwave. Production of smaller cubical structures due to cracking of MAP crystals during microwave irradiation should increase the practical surface area to contact with liquor, and this would be one reason of higher dissolution rate of MAP during microwave irradiation. High temperature with vibration also could induce the dissolution. Sanz et al. (2003) showed that microwave irradiation dissociates the hydrogen peroxide and generates hydroxyl radicals due to the excitation of the molecule to high vibrational and rotational energy levels. Break down of MAP crystals occurred due to this high vibrational and rotational energy. Dissolution of MAP crystals also might be easy with the microwave irradiation due to presence of hydrogen bond in MAP (Ponne and Bartles, 1995).

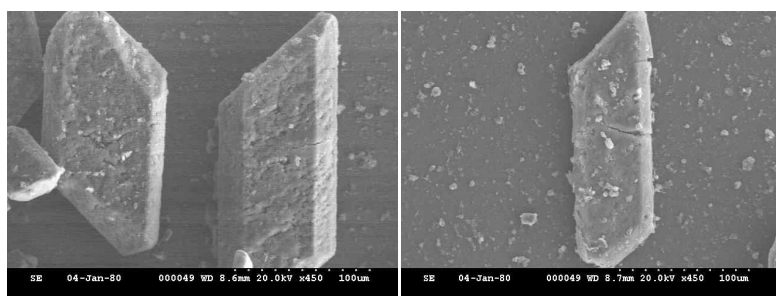

1) $5 \mathrm{sec}$

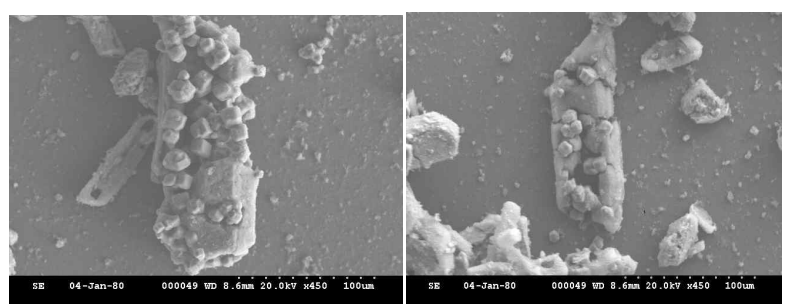

3) $15 \mathrm{sec}$ 4) $20 \mathrm{sec}$

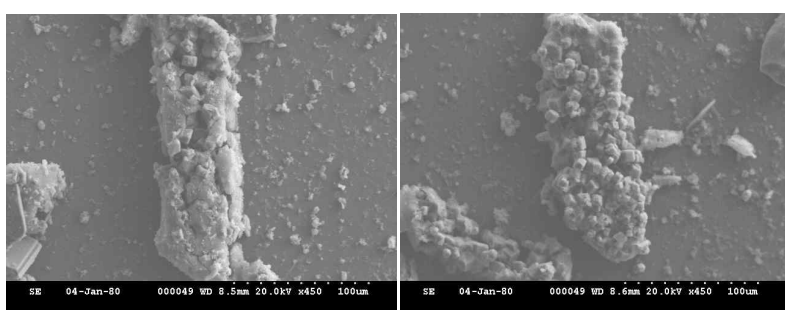
6) $30 \mathrm{sec}$
Liao et al. (2005) stated that microwave irradiation acts as a generator agent of oxidizing radicals as well as a heating source in the process of dissolution of phosphate from secondary municipal sludge.

\section{ABSTRACT}

The feasibility of reutilization of magnesium ammonium phosphate (MAP) or struvite slurry recovered from the process through microwave irradiation was studied in this experiment. For this purpose, 4 different operations were performed with or without $\mathrm{Mg}$ source addition and different levels of MAP recycled in a batch reactor. Dissolution rate of $\mathrm{MAP}, \mathrm{NH}_{4}{ }^{+}$elimination pattern and physicochemical changes of MAP during microwave irradiation were also studied. The result showed that only $33 \%$ orthophosphate $\left(\mathrm{PO}_{4}-\mathrm{P}\right)$ and $27 \% \quad \mathrm{NH}_{4}-\mathrm{N}$ removal occurred without adding any external $\mathrm{Mg}$ source (run $\mathrm{A}$ ), whereas $87 \% \mathrm{PO}_{4}-\mathrm{P}$ and $40 \% \mathrm{NH}_{4}-\mathrm{N}$ removed when $1.0 \mathrm{M}$ ratio of $\mathrm{MgCl}_{2}$ (run B) was added based on $\mathrm{PO}_{4}-\mathrm{P}$ in influent. Although the addition of 1.0 molar ratio of microwave irradiated MAP (Run C) removed lower $\mathrm{PO}_{4}-\mathrm{P}$ and $\mathrm{NH}_{4}-\mathrm{N}$ than $1.0 \mathrm{M} \mathrm{MgCl}_{2}$ (run $\mathrm{B}$ ), $\mathrm{PO}_{4}-\mathrm{P}$ removal was double when compared with no $\mathrm{Mg}$ addition (run A). Addition of half MAP and half $\mathrm{MgCl}_{2}$ (run D) showed the similar removal efficiency $\left(88 \% \mathrm{PO}_{4}-\mathrm{P}\right.$ and $\left.35 \% \mathrm{NH}_{4}-\mathrm{N}\right)$ with sole $\mathrm{MgCl}_{2}$ addition (run B). Based on these results, the reutilization of MAP irradiated by microwave would be a feasible way to enhance the removal efficiencies of $\mathrm{N}$ and $\mathrm{P}$, as well as curtail the $\mathrm{Mg}$ chemical usage. Track study showed that $\mathrm{NH}_{4}-\mathrm{N}$ gradually increased at initial stage of microwave irradiation of MAP, and then started eliminating from liquor as temperature increased over $45^{\circ} \mathrm{C}$. Dissolution rate of $\mathrm{PO}_{4}{ }^{-3}$ during microwave irradiation was proportional to the initial MAP concentration, having $0.0091 \mathrm{x}^{0.6373} \mathrm{mg} / \mathrm{sec}$. It was found from the scanning electron microscope (SEM) study that physical structure of MAP crystal started breaking down into small cube granules within very short time by electromagnetic vibration force during microwave irradiation and then gradually melted down into solution.

\section{ACKNOWLEDGEMENTS}

We are grateful to the funding by Korea Research Foundation (Project. No., F00044). Also, this work was supported in part by a grant from the institute of Animal Resources at Kangwon National University, Korea.

Fig. 4. Photographs of MAP (with SEM, x450). 


\section{REFERENCES}

1. Ahn, P. B., Kim, J. H. and Hwang, J. S. 2004. Use of microwave pretreatment for enhanced anaerobiosis of secondary sludge. Water Sci. Technol. 50(9):17-23.

2. Bi, X. Y., Wang, P., Jiang, I. H., Xu, H. Y., Shi, S. J. and Huang, J. L. 2007. Treatment of phenol wastewater by microwave-induced $\mathrm{ClO}_{2}-\mathrm{CuOx} / \mathrm{Al}_{2} \mathrm{O}_{3}$ catalytic oxidation process. J. Environ. Sci. 19:1510-1515.

3. Bonmati, A. and Flotats, X. 2003. Air stripping of ammonia from pig slurry: characterization and feasibility as a pre- of post-treatment to mesophilic anaerobic digestion. Waste Manag. 23:261-272.

4. Chan, W. I., Wong, W. T., Liao, P. H. and Lo, K. V. 2007. Sewage sludge nutrient solubilization using a single-stage microwave treatment. J. Environ. Sci. Heal., Part-A. 42(1): 59-63.

5. Chirmuley, D. G. 1994. Struvite precipitation in WWTPs: Causes and solutions. Water (J. Austr. Water Assoc.) December. 21-23.

6. Eskicioglu, C., Terzian, N., Kennedy, K. J., Drostea, R. L. and Hamoda, M. 2007. A thermal microwave effects for enhancing digestibility of waste activated sludge. Water Res. 41:24572466 .

7. Jaffer, Y., Clark, T. A., Pearce, P. and Parsons, S. A. 2002. Potential phosphorus recovery by struvite formation. Water Res. 36(7):1834-1842.

8. Jeong, B. Y., Song, S. H., Baek, K. W., Cho, I. H. and Hwang, T. S. 2006. Preparation and properties of heterogeneous cation exchange membrane for recovery of ammonium ion from waste water. Polymer (Korea). 30:486-491.

9. Kim, K. W., Kim, Y. J., Kim, I. T., Park, G. I. and Lee, E. H. 2006. Electrochemical conversion characteristics of ammonia to nitrogen. Water Res. 40:1431-1441.

10. Lee, S. I., Weon, S. Y., Lee, C. W. and Koopman, B. 2003. Removal of nitrogen and phosphate from wastewater by addition of bittern. Chemosphere. 51:265-271.

11. Li, X. Z., Zhao, Q. L. and Hao, X. D. 1999. Ammonium removal from landfill leachate by chemical precipitation. Waste Manag. 19:409-415.

12. Liao, P. H., Wong, W. T. and Lo, K. V. 2005. Advanced oxidation process using hydrogen peroxide/microwave system for solubilization of phosphate. J. Environ. Sci. Heal., Part-A. 40(9):1753-1761.

13. Lin, L, Yuan, S., Chen, J., Xu, Z. and Lu, X. 2009. Removal of ammonia nitrogen in wastewater by microwave radiation. $\mathrm{J}$. hazard. Mater. 161 (2-3):1063-1068.

14. Martin, D. I., Margaritescu, I., Cirstea, E., Togoe, I., Ighigeanu, D., Nemtanu, M. R., Oproiu, C. and Iacob, N. 2005. Application of accelerated electron beam and microwave irradiation to biological waste treatment. Vacuum. 77(4):501-506.

15. Menendez, J. A., Inguanzo, M. and Pis, J. J. 2002. Microwave induced pyrolysis of sewage sludge. Water Res. 36:3261-3264.

16. Munch, E. V. and Barr, K. 2001. Controlled struvite crystallisation for removing phosphorus from anaerobic digester sidestreams. Water Res. 35(1):151-159.

17. Ponne, C. T. and Bartels, P. V. 1995. Interaction of electromagnetic energy with biological material-relation to food processing. Radiation Phys. Chem. 45(4):591-607.

18. Qureshi, A., Lo, K. V. and Liao, P. H. 2008. Microwave treatment and struvite recovery potential of dairy manure. J. Environ. Sci. Heal., Part-B, 43(4):350-357.

19. Saillard, R., Poux, M., Berlan, J., Audhuy-Peaudecerf, M. 1995. Microwave heating of organic solvents: thermal effects and field modelling. Tetrahedron 51(14):4033-4042.

20. Sanz, J., Lombrana, J. I., Luis, A. M. D., Ortueta, M. and Varona, F. 2003. Microwave and Fenton's reagent oxidation of wastewater. Environ. Chem. Lett. 1:45-50.

21. Suzuki, K., Tanaka, Y., Kuroda, K., Hanajima, D. and Fukumoto, Y. 2005. Recovery of phosphorous from swine wastewater through crystallization. Bioresour. Technol. 96(14): 1544-1550.

22. Welander, U., Henrysson, T. and Welander, T. 1998. Biological nitrogen removal from municipal landfill leachate in a pilot scale suspended carrier biofilm process. Water Res. 32:1564-1570.

23. Wojciechowska, E. 2005. Application of microwaves for sewage sludge conditioning. Water Res. 39(19):4749-4754.

24. Wong, W. T., Chan, W. I., Liao, P. H. and Lo, K. V. 2006. A hydrogen peroxide/microwave advanced oxidation process for sewage sludge treatment. J. Environ. Sci. Heal., Part-A. 41 (11):2623-2633.

25. Yetilmezsoy, K. and Zengin, Z. S. 2009. Recovery of ammonium nitrogen from the effluent of UASB treating poultry manure wastewater by MAP precipitation as a slow release fertilizer. J. Hazard. Mater. 166:260-269.

26. Zhang, T., Lili, Ding, L. and Ren, H. 2009. Pretreatment of ammonium removal from landfill leachate by chemical precipitation. J. Hazard. Mater. 166:911-915.

(접수일자 : 2009. 7. 13. / 수정일자 : 2009. 8. 12. /

채택일자 : 2009. 8. 14.) 